\title{
Losartan improves the therapeutic effect of metronomic cyclophosphamide in triple negative mammary cancer models
}

\author{
Leandro E. Mainetti ${ }^{1,2, *}$, María José Rico ${ }^{1,2, *}$, Cintia Daniela Kaufman ${ }^{1,2}$, Monica \\ Carolina Grillo ${ }^{1}$, Julian Guercetti ${ }^{1}$, María Virginia Baglioni ${ }^{1,2}$, Antonela Del Giúdice ${ }^{1,2}$, \\ Maria Celeste Capitani ${ }^{1}$, Matias Fusini ${ }^{1}$, Viviana Rosa Rozados ${ }^{1,2, \#}$ and O. Graciela \\ Scharovsky ${ }^{1,2,3, \#}$ \\ ${ }^{1}$ Instituto de Genética Experimental, Facultad de Ciencias Médicas, Universidad Nacional de Rosario, Rosario, Argentina \\ ${ }^{2}$ Consejo Nacional de Investigaciones Científicas y Técnicas, Buenos Aires, Argentina \\ ${ }^{3}$ Metronomics Global Health Initiative, Marseille, France \\ *These authors contributed equally and are co-first authors \\ \#These authors contributed equally and are co-senior authors \\ Correspondence to: Leandro E. Mainetti, email: leandromainetti@gmail.com
}

Keywords: mammary cancer; metronomic chemotherapy; drug repurposing; cyclophosphamide; losartan

Received: March 17, 2020

Accepted: May 25, 2020

Published: August 11, 2020

Copyright: Mainetti et al. This is an open-access article distributed under the terms of the Creative Commons Attribution License 3.0 (CC BY 3.0), which permits unrestricted use, distribution, and reproduction in any medium, provided the original author and source are credited.

\section{ABSTRACT}

Metronomic chemotherapy refers to the minimum biologically effective doses of a chemotherapy agent given as a continuous regimen without extended rest periods. Drug repurposing is defined as the use of an already known drug for a new medical indication, different from the original one. In oncology the combination of these two therapeutic approaches is called "Metronomics".

The aim of this work is to evaluate the therapeutic effect of cyclophosphamide in a metronomic schedule in combination with the repurposed drug losartan in two genetically different mice models of triple negative breast cancer.

Our findings showed that adding losartan to metronomic cyclophosphamide significantly improved the therapeutic outcome. In both models the combined treatment increased the mice's survival without sings of toxicity. Moreover, we elucidated some of the mechanisms of action involved, which include a decrease of intratumor hypoxia, stimulation of the immune response and remodeling of the tumor microenvironment.

The remarkable therapeutic effect, the lack of toxicity, the low cost of the drugs and its oral administration, strongly suggest its translation to the clinical setting in the near future.

\section{INTRODUCTION}

Cancer is a disease caused by the accumulation of genetic and epigenetic changes. According to global cancer statistics, about 2.1 million female breast cancer were to be diagnosed in 2018, thus accounting for almost 1 in 4 cancer cases among women [1]. Standard clinical protocols for cancer chemotherapy typically employ the maximum drug dose that can be tolerated by the patient (MTD). These regimens lead, in turn, to the need for drugfree periods between treatment cycles to allow normal tissue recovery from the cytotoxic attack; they are ideally designed to maximize tumor cell killing without lethal damage to the patient. Nevertheless, as a counterpart of its effectiveness, its high toxicity has detrimental effects on the patients' quality of life and, also, the treatment can lead to the development of therapeutic resistance [2]. In contrast to MTD regimens, metronomic chemotherapy (MCT) is characterized by the chronic, equally spaced administration of (generally) low doses of chemotherapeutic drugs, without extended rest periods [3-5]. The novelty of this treatment modality, known as anti-angiogenic therapy, lies in its main cell target, the tumor endothelial cell [6]. Also, another mechanism of action of MCT include activation of anti-tumor immunity [7].

Drug repurposing is a creative and resourceful approach to increase the number of therapies by exploiting available and already approved drugs. In oncology, drug 
repurposing is gathering momentum, mainly because revolutionary advances in pharmacology and genomics have demonstrated that many old drugs, designed for other indications, have antitumor activity [8]. Drug repurposing is frequently used with MCT, a combination of therapeutic approaches that has been defined as "Metronomics" [9].

Cyclophosphamide (Cy), one of the most frequently used alkylating agents, has shown antitumor activity when administered with a metronomic schedule [10-12].

Losartan (Los), is an angiotensin II receptor type 1 antagonist, approved to control hypertension in patients [13] and, it is also an antifibrotic agent shown to reduce the incidence of cardiac and renal fibrosis [14, 15]. As a repurposed drug for cancer treatment, Los reduces stromal collagen, improving drug and oxygen delivery to tumors, thereby potentiating chemotherapy and reducing hypoxia in breast and pancreatic cancer models [16].

We report here that the combined metronomic treatment of Cy plus Los, used in two triple negative mammary adenocarcinoma murine models, inhibited tumor growth, increased survival and was devoid of general toxic effects, showing that Los can increase the therapeutic effectiveness of MCT with $\mathrm{Cy}$.

\section{RESULTS}

\section{Antitumor effect}

The effect on tumor growth of MCT with low doses Cy plus Los was studied by implanting orthotopically in the mammary fat pad, M-234p or M-406 mammary adenocarcinomas in $\mathrm{BALB} / \mathrm{c}$ or $\mathrm{CBi}$ mice, respectively. As can be seen in Figure 1A, the treatment with $\mathrm{Cy}+\mathrm{Los}$ significantly inhibited the growth of M-234p tumors, compared to non-treated Control and Los groups, from day 21 onwards $(P<0.05)$. A similar effect was observed in the M-406 tumor model (Figure 1B). The mean volume of M-406 tumors in Control group was higher, on day 17, than in that of $\mathrm{Cy}(P<0.01)$, Los $(P<0.05)$ and $\mathrm{Cy}+\mathrm{Los}$ $(P<0.001)$ groups.

\section{Survival}

As a consequence of the anti-tumor effect, there was an increase in survival. M-234p bearing mice that received the combined treatment $\mathrm{Cy}+$ Los showed a significantly higher survival than that of Control group (Median Survival [MS]: 34 days; $P<0.01)$, Cy (MS: 47 days; $P$ $<0.01$ ), and Los (MS: 32 days; $P<0.01$ ) (Figure 1C), while Control, Cy and Los groups did not differ from each other. Importantly, by day 60, all the mice in Control, Cy and Los groups had already been sacrificed, because of their tumor burden, but none of the mice in the $\mathrm{Cy}+\mathrm{Los}$ group. In the combined treatment group, two animals were sacrificed on days 73 and 79 , respectively, while the remaining three animals $(3 / 5 ; 60 \%)$ showed complete tumor regression (MS: undefined). The treatment of these mice was discontinued on day 80 . Interestingly, after 20 more days without treatment, until the end of the experiment (Day 100), no recurrences were detected.

In the M-406 tumor model, when compared to Control (MS: 24) group, the different treatments significantly increased survival, Cy (MS: 36.5 days; $P<$ 0.01), Los (MS: 33 days; $P<0.01$ ), and Cy+Los (MS: 47 days; $P<0.001)$. Also, $\mathrm{Cy}+\mathrm{Los}$ group showed a significantly higher survival than $\mathrm{Cy}(P<0.05)$ and Los $(P<0,001)$. In spite of the fact that no tumor regressions were achieved in this tumor model, the median survival time in $\mathrm{Cy}+\mathrm{Los}$ group almost duplicated that of the Control group (24 vs 47 days) (Figure 1D).

\section{Toxicity}

When monitoring several signs related to toxicity in both tumor models, treated animals showed normal traits in food intake, response to stimuli, motor activity, breathing and fur quality. Also, the treatments did not cause weight loss (Supplementary Figure 1).

\section{Mechanisms of action}

\section{Proliferation}

In the M-234p and M-406 tumor models, the group treated with $\mathrm{Cy}+$ Los showed significantly lower Ki67 tumor expression when compared to Control group $(P<$ 0.01 and $P<0.05$, respectively) (Figure 2A-2D).

\section{Apoptosis}

In the M-234p tumor model, the number of TUNEL ${ }^{+}$ cells in $\mathrm{Cy}+\mathrm{Los}$ group was higher than in that of Control group $(P<0.05)$, (Figure $2 \mathrm{E}$ and $2 \mathrm{G})$. On the other hand, no significant differences were found among groups in the M-406 model (Figure 2F and 2H).

\section{Angiogenesis}

The morphology of tumor blood vessels was analyzed in samples stained with $H \& E$ by a trained pathologist. The results were similar for both tumor models. The capillaries in Control group samples showed a thin and interrupted connective tissue sheet. The inner layer is characterized by small endothelial cells with flat nuclei and intercellular gaps forming a discontinuous vessel. It is important to notice the lack of pericytes (or cells that by structure and staining are compatible with pericytes) surrounding the capillary. On the other hand, samples from the group treated with $\mathrm{Cy}+$ Los showed intraand peritumoral capillaries with structure and morphology similar to capillaries that irrigate normal tissues. Endothelial cells provide a continuous uninterrupted lining, with a complete and well defined basal membrane covered with pericytes. Samples from tumors belonging to $\mathrm{Cy}$ or Los groups showed vessels and capillaries with a structure 
and morphology similar to Control group (Figure 3A-3D). Furthermore, the effect of the treatment on intratumor hypoxia was analyzed by immunohistochemistry with HIF1- $\alpha$ expression. The treatment with $\mathrm{Cy}$, in both tumor models, and with $\mathrm{Cy}+\mathrm{Los}$ in M-406 tumors, decreased significantly the number of HIF $1-\alpha$ positive cells per field compared to Control group $(P<0.05)$ (Figure 3E-3H).

\section{Immune cells populations}

The percentage of circulating $\mathrm{CD}^{+}$and $\mathrm{CD} 8^{+}$cells did not show, on day 30, significant differences among groups in any of the two models (Figure 4A, 4B, 4E and $4 \mathrm{~F})$. Also, in the M-234p model there were no differences among groups in circulating Treg $\left(\right.$ Foxp $\left.^{+}\right)$and Th17 cell populations (Figure 4C and 4D); on the contrary, in the M-406 model the number of Treg cells in Los and Cy+Los groups were lower $(P=0.064)$, and the number of Th17 cells were higher in the same groups $(P<0.01)$, when compared to Control group (Figure $4 \mathrm{G}$ and $4 \mathrm{H}$ ).

When quantifying the tumor infiltrating $\mathrm{CD}^{+}$and $\mathrm{CD}^{+}$cells, no significant differences among groups were found, on day 30, in none of the two models (Figure 5A, $5 \mathrm{~B}, 5 \mathrm{D}, 5 \mathrm{E}, 5 \mathrm{G}, 5 \mathrm{H}, 5 \mathrm{~J}$ and $5 \mathrm{~K})$. Besides, the analysis of the tumor infiltrating Treg cells in samples taken on day 30, showed the opposite behavior in each tumor model. Samples of M-234p tumors from animals treated with $\mathrm{Cy}+\mathrm{Los}$ had a significantly higher number of Foxp $3^{+}$cells compared to that of Control group $(P<0.05)$ (Figure $5 \mathrm{C}$ and $5 \mathrm{~F})$. On the other hand, in the M-406 tumor samples, a significant decrease in the number of Treg cells in Cy+Los group $(P$ $<0.05$ ) (Figure 5I and 5L) was found. Moreover, M-234p tumor samples were taken on day 42, a time point when all the mice in Control and Los groups were euthanized. Tumor infiltrating lymphocytes populations were analyzed by flow cytometry. Interestingly, at this time, the number of Treg cells was significantly lower and Th17 cells significantly higher in $\mathrm{Cy}+\mathrm{Los}$ group compared to those of Cy group ( $P$ $<0.001$ and $P<0.05$, respectively) (Figure 6C and 6D). As in day 30 quantifications, no differences were found for the $\mathrm{CD}^{+}$and $\mathrm{CD}^{+}$cells (Figure $6 \mathrm{~A}$ and $6 \mathrm{~B}$ ).

\section{Cancer Associated Fibroblasts (CAF)}

The number and activity of CAF were evaluated by IHC through the aSMA expression and the Picro Sirius Red staining for collagen quantification. The $\%$ of $\alpha \mathrm{SMA}^{+}$ area was significantly lower in the $\mathrm{Cy}+\mathrm{Los}$ group when
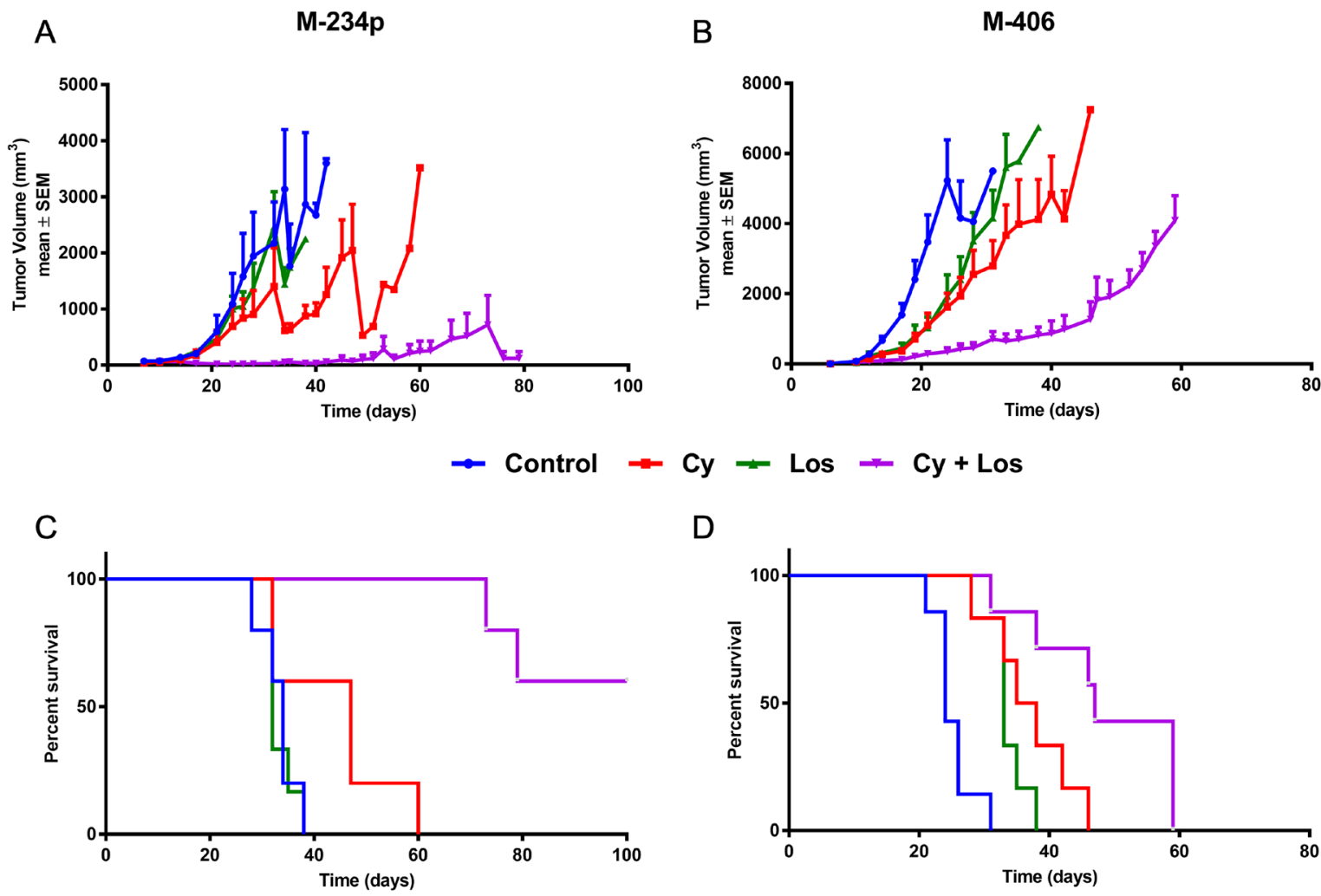

D

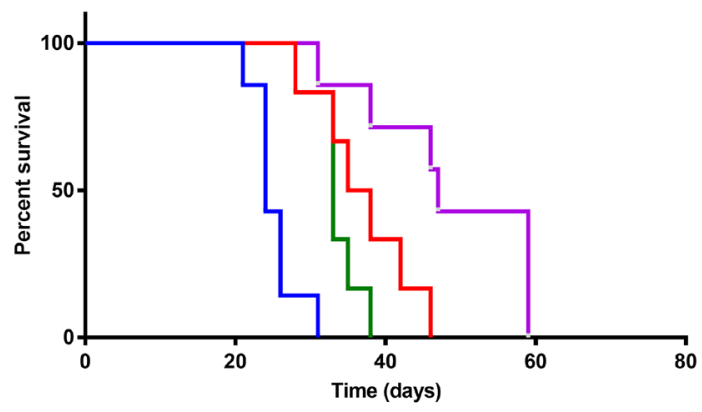

Figure 1: Tumor growth and overall survival. Tumor growth assessment: data for each time-point in $\mathrm{mm}^{3}$ are mean $\pm \mathrm{SEM}$. (A) M-234p, $N=6$ /group; Day 21: Control (600.96 \pm 93) vs Cy+Los $(20.96 \pm 9.01)(P<0.05)$; (B) M-406, $N=6-7 /$ group; Day 17: Control $(1397.00 \pm 328.32)$ vs Cy $(372.00 \pm 55.25)(P<0.01)$, vs Los $(451.07 \pm 143.94)(P<0.05)$, vs Cy+Los $(123.43 \pm 45.71)(P<0.001)$. Kruskal-Wallis multiple comparison test and Dunn's post-test. Overall survival (Kaplan-Meier), Median Survival (MS): (C) M-234p, $N$ = 5-6/group; Control (MS: 34 days); Cy (MS: 47 days); Los (MS: 32 days); Cy+Los (MS: undefined, Day 32: 60\% [3/5] complete tumor regressions). $\mathrm{Cy}+\mathrm{Los}$ vs Control, vs Los, vs Cy $(P<0.01)$; (D) M-406, $N=6-7 /$ group); Control (MS: 24 days); Cy (MS: 36.5 days); Los (MS: 33 days); $\mathrm{Cy}+\mathrm{Los}(\mathrm{MS}: 47$ days). Control vs $\mathrm{Cy}(P<0.01)$, vs Los $(P<0.01)$, vs Cy+Los $(P<0.001)$; Cy+Los vs Cy $(P<0.05)$, vs Los $(P<0,001)$. Log-rank Test. 
compared to Control animals in both tumor models ( $P$ $<0.01$ ) (Figure 7A-7D). The area occupied by collagen in the tumor samples of the three treated groups in both models was lower than that of Control group, showing a significant difference between $\mathrm{Cy}+\mathrm{Los}$ and Control groups in the M-234p model $(P<0.01)$ (Figure 7E-7H).

\section{DISCUSSION}

Metronomic chemotherapy has come a long way since the first publications in $2000[3,5]$. This therapeutic approach has demonstrated its efficacy for the treatment of different types of cancer [17-20]. Cyclophosphamide

A

M-234p
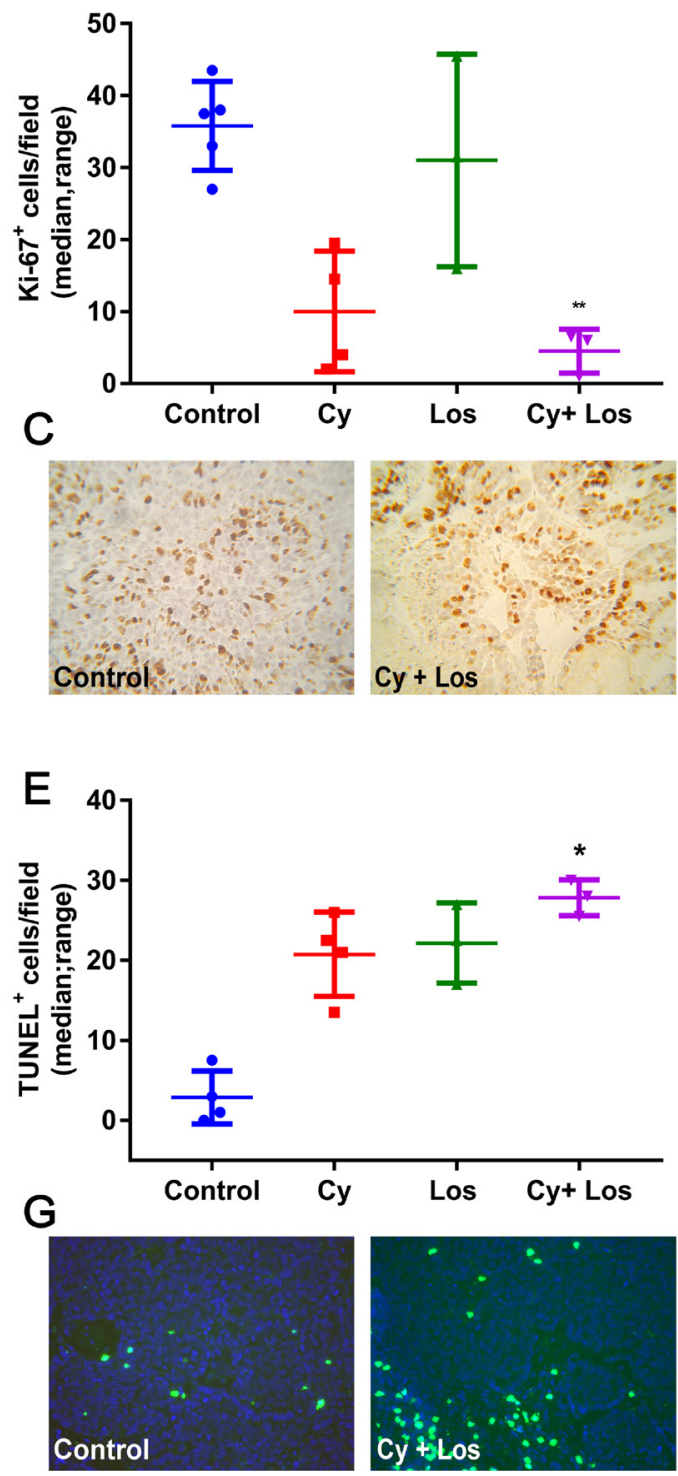

is among the first cytotoxic drugs used in a metronomic schedule [21, 22]. In our own experience, we have administered metronomic $\mathrm{Cy}$, alone or in combination with other drugs, in several preclinical models and in a clinical trial [10, 11, 23-25]. Losartan has been used lately as repurposed drug in cancer treatment [26, 27]. Although its therapeutic effect as a single drug is poor, its combination with other antitumor agents highly enhances its efficacy. Such effect could be due, in part, to a decrease in the extracellular matrix collagen expression which, in turn, would improve drug delivery into the tumor [28, 29].

We found that the combined treatment with Cy+Los, in both triple negative mammary tumor models, inhibited
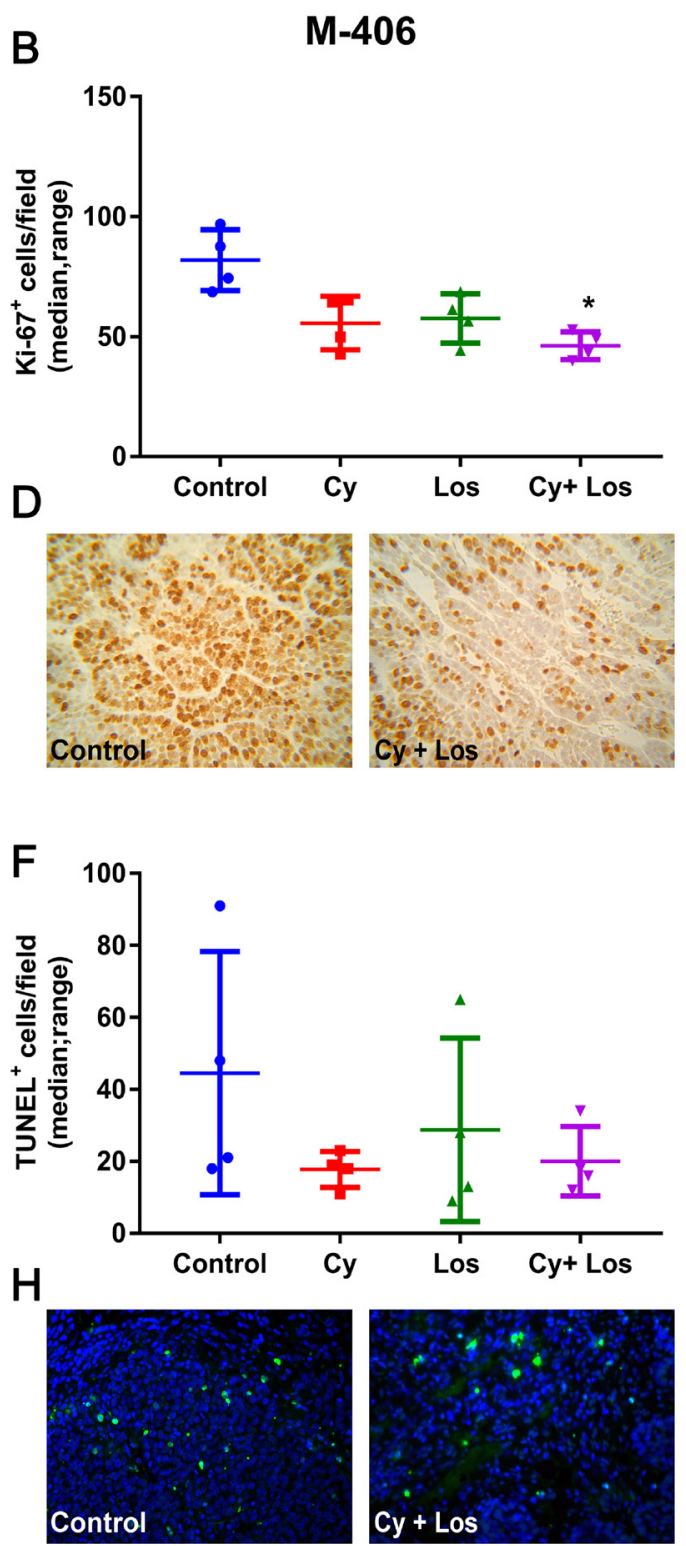

Figure 2: Ki67 expression and apoptosis quantification. Proliferation: Ki67 ${ }^{+}$cells/field (median, range). (A) M-234p Control vs Cy+Los $(P<0.01)$; (B) M-406 Control vs Cy+Los $(P<0.05$; (C) M-234p and (D) M-406, representative images of Control and Cy+Los treated tumors, $1000 \times$ magnification. Apoptosis: TUNEL ${ }^{+}$cells/field (median, range). (E) M-234p Control vs Cy+Los $(P<0.05):(\mathbf{F})$ M-406 N. S; Kruskal-Wallis multiple comparison test and Dunn's post-test; (G) M-234p and (H) M-406 representative images of Control and $\mathrm{Cy}+\mathrm{Los}$ treated tumors, $1000 \times$ magnification. 


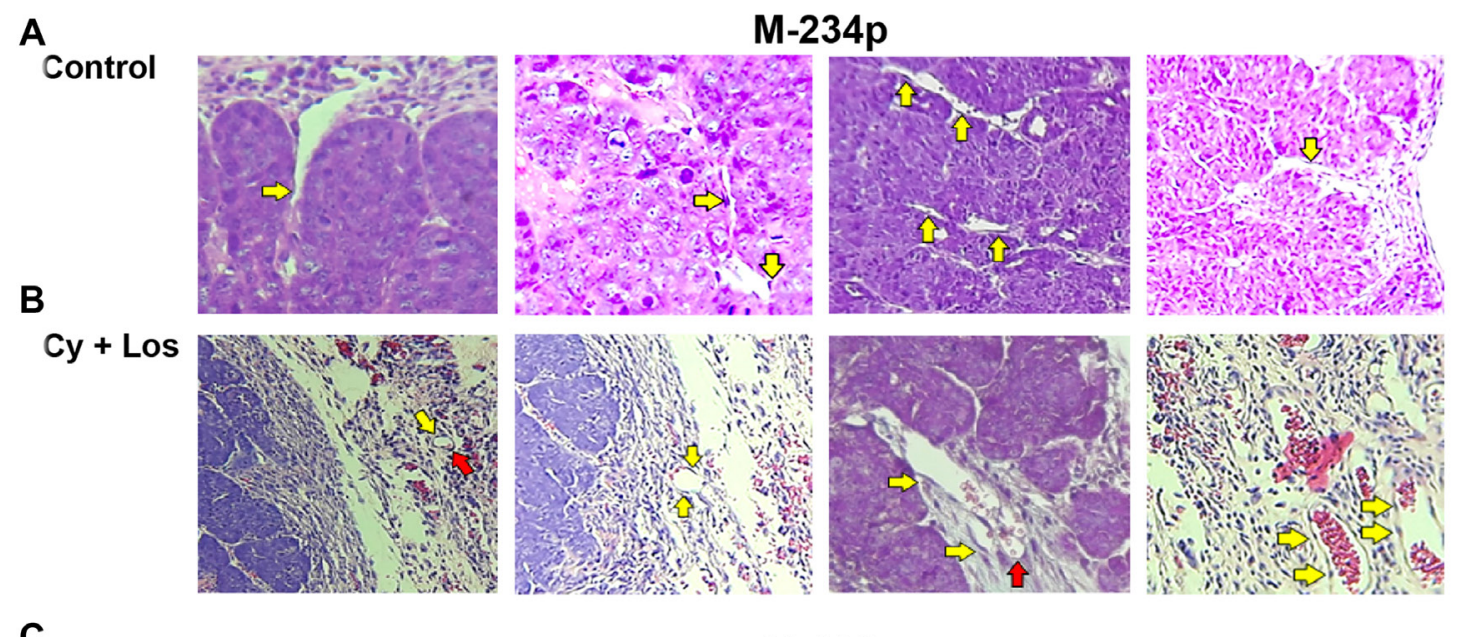

C

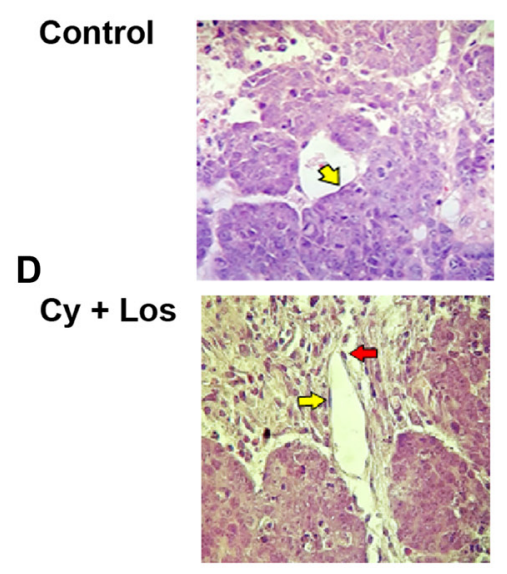

-406

E

\section{M-234p}

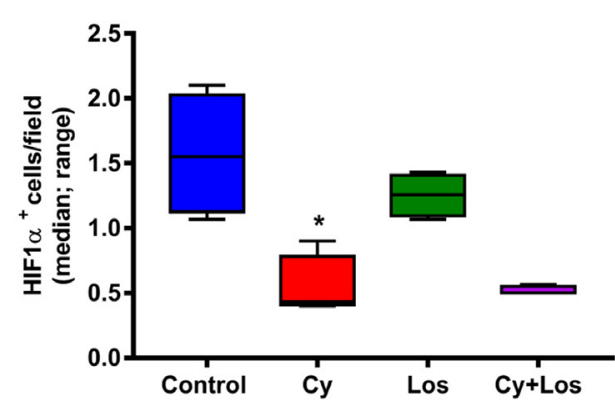

G
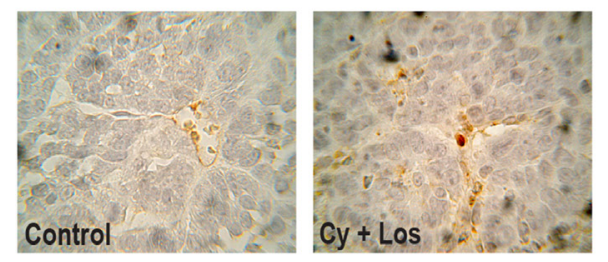

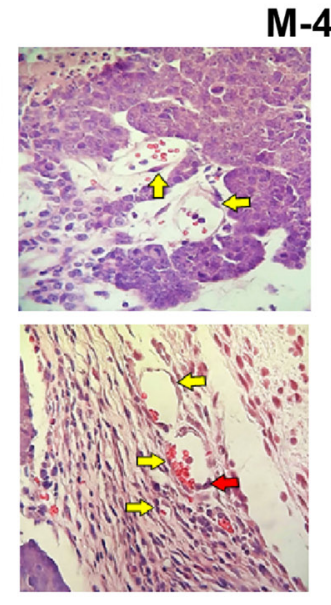

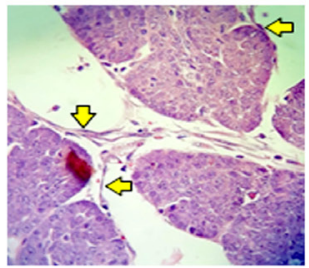

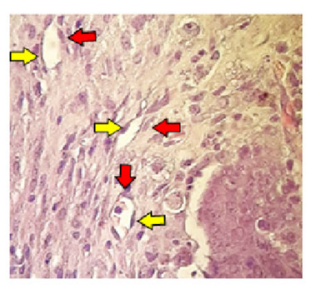

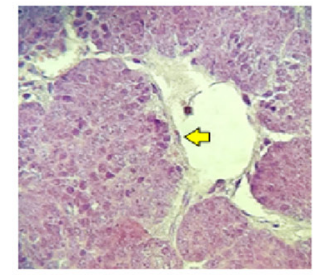

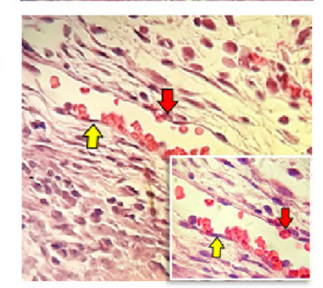

M-406

$\mathbf{F}$

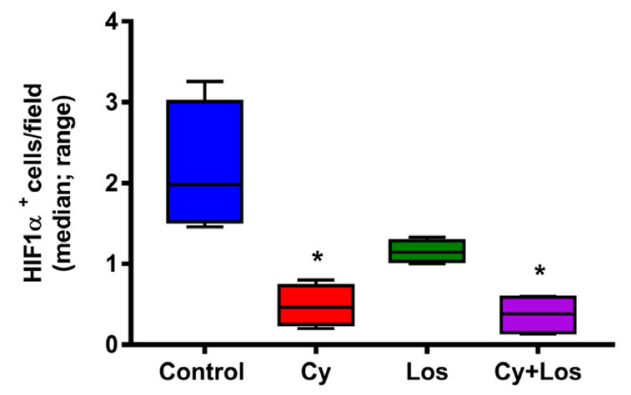

H
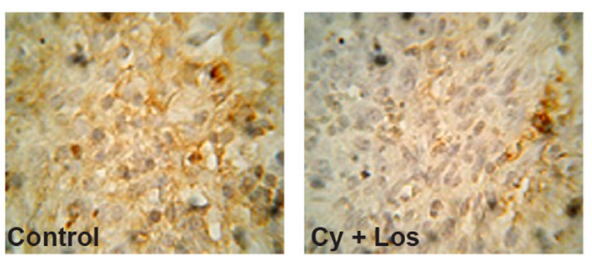

Figure 3: Vascular normalization. Hematoxylin and eosin (H\&E) representative tumor sections from M-234p and M-406, 400×. In both models the behavior was similar. Control group: (A) M-234p and (C) M-406: capillaries with small endothelial cells with barely stained nuclei and intercellular gaps (yellow arrow), lack of pericytes or cells with structure and staining compatible with pericytes. Cy+Los group: (B) M-234p and (D) M-406: intra- and peritumoral capillaries with structure and morphology similar to normal tissues. Endothelial cells with defined nuclei provide a continuous uninterrupted lining (yellow arrow), and well defined basal membrane covered with pericytes (red arrow). M-406 magnified section $(1000 \times)$ : vessel with normal vascular morphology. HIF1 $\alpha$ expression: HIF $1 \alpha^{+}$cells/field (median, range). (E) Control vs Cy $(P<0.05)$, (F) Control vs Cy $(P<0.05)$, vs $\mathrm{Cy}+\mathrm{Los}(P<0.05),(\mathbf{G})$ and $\mathbf{H})$, representative images of Control and $\mathrm{Cy}+$ Los treated tumors, $100 \times$ magnification. Kruskal-Wallis multiple comparison test and Dunn's post-test. 

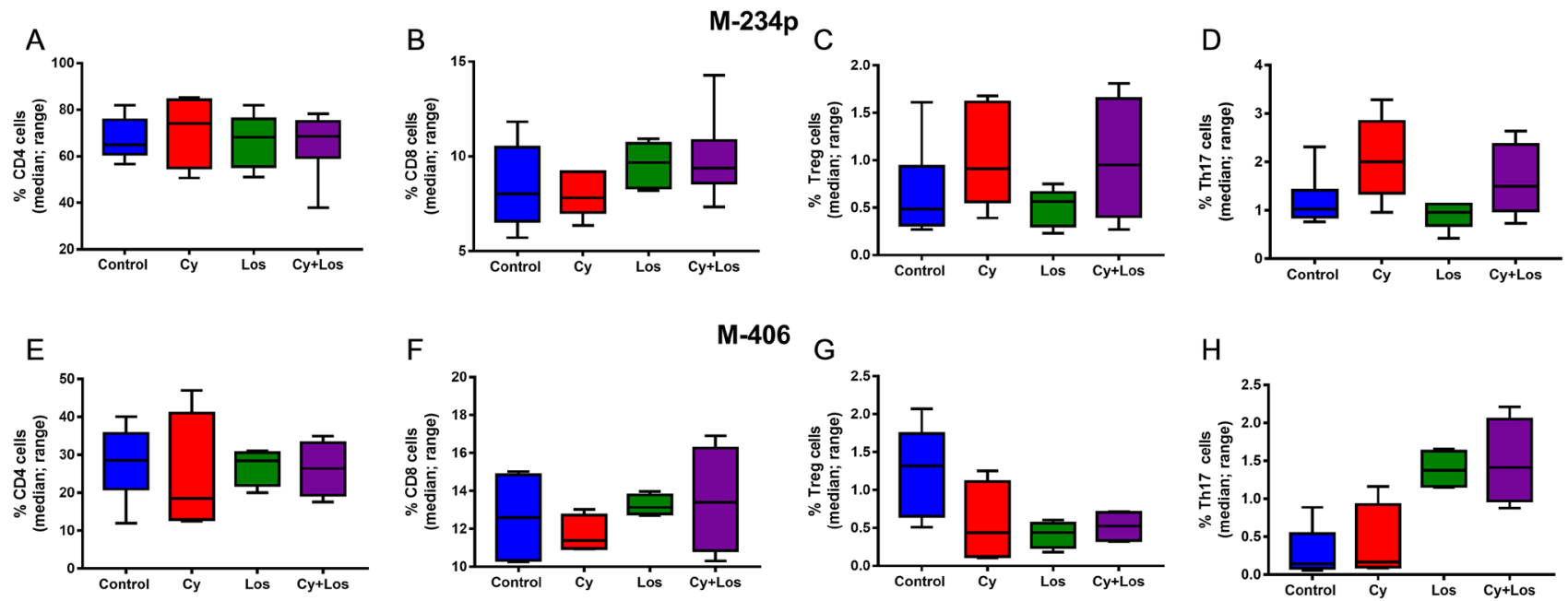

Figure 4: Quantification of circulating T cells by flow cytometry: \% of positive cells (median, range). M-234p: (A) CD4 cells, N. S. (B) CD8 cells, N. S. (C) Treg cells, N. S. (D) Th17 cells, N. S. M-406: (E) CD4 cells, N. S. (F) CD8 cells, N. S. (G) Treg cells, $(P=0.064)$. (H) Th17 cells: Control vs Cy+Los, $(P=0.0580)$. Kruskal-Wallis multiple comparison test and Dunn's post-test.

A

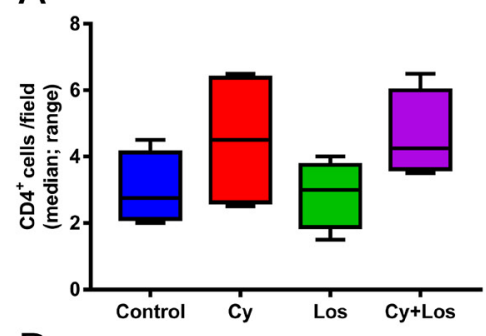

$\mathrm{D}$

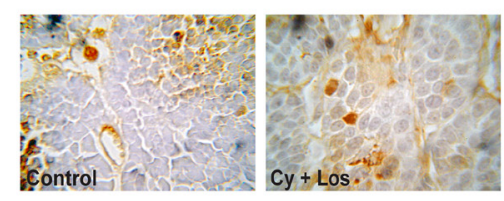

G

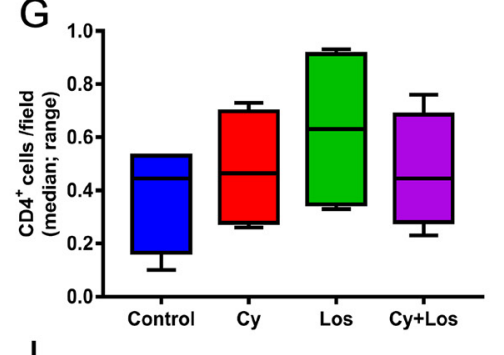

J

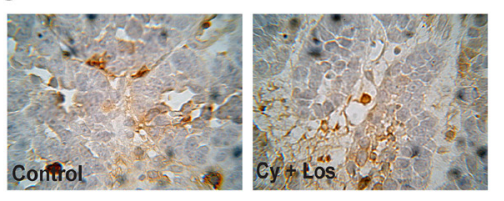

B

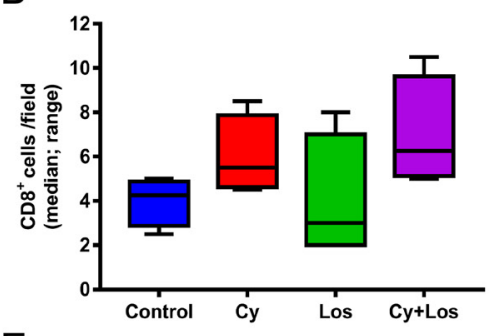

$\mathrm{E}$
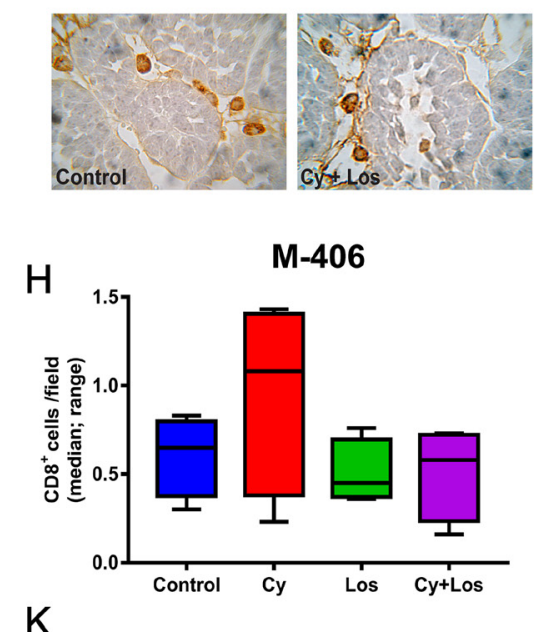

$\mathrm{K}$

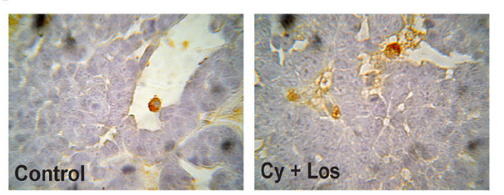

C

F
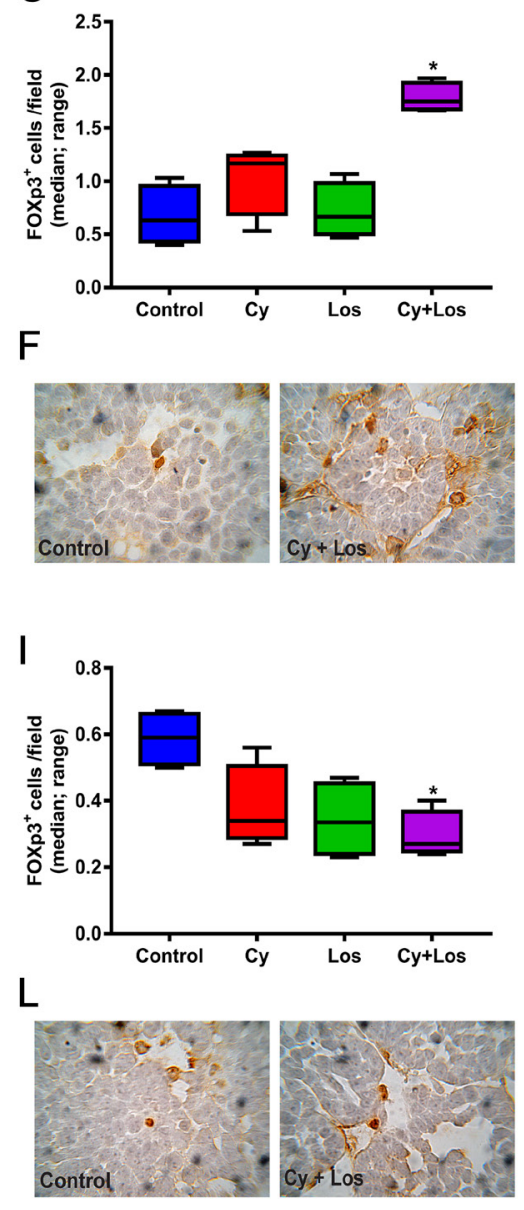

Figure 5: Quantification of tumor infiltrating lymphocytes by IHC. Lymphocytes/field (median, range). M-234p: (A) CD4+ cells, N. S. (B) CD8 ${ }^{+}$cells, N. S. (C) Foxp3 ${ }^{+}$cells: Control vs Los, $P<0.05$, vs Cy+Los, $(P<0.05)$; (D-F) representative images of Control and $\mathrm{Cy}+$ Los treated tumors, $100 \times$ magnification; M-406: (G) CD4 ${ }^{+}$cells, N. S. (H) CD8 ${ }^{+}$cells, N. S. (I) Foxp3 ${ }^{+}$cells: Control vs Cy+Los, $(P<0.05)$; $(\mathbf{J}-\mathbf{L})$ representative images of Control and Cy+Los treated tumors, $100 \times$ magnification. Kruskal-Wallis multiple comparison test and Dunn's post-test. 
tumor growth and, interestingly, was more efficient than the treatments with each drug alone, resulting in a very significant increase in the overall survival. Importantly, in the M-234p tumor model, the combined treatment led to a $60 \%$ of tumor regressions, which lasted, without recurrences, even 20 days after discontinuation of therapy. On the other hand, no regressions were observed in M-406 tumor model. Nevertheless, the encouraging result was that the combined treatment duplicated the median survival time of M-406 tumor bearers.

The observation of different behaviors in the tumor models is interesting, because, as it is the case in human cancers, the different genetic backgrounds in hosts and, therefore, in their tumors, lead to different therapeutic outcomes. In the development of a malignant tumor and of the derived metastasis are involved a high number of both, genetic and epigenetic events. Hence, those characteristics will shape the response to treatments of different lines of mice.

One of the advantages of the therapeutic approach called Metronomics is that it has low toxicity [30]. In fact, we found that the treatment did not cause weight loss, nor did it cause any alterations in the markers of morbidity/ toxicity monitored, in none of the two tumor models.

Nowadays, metronomic chemotherapy is defined as a multitarget therapy [31], a fact that suggests the
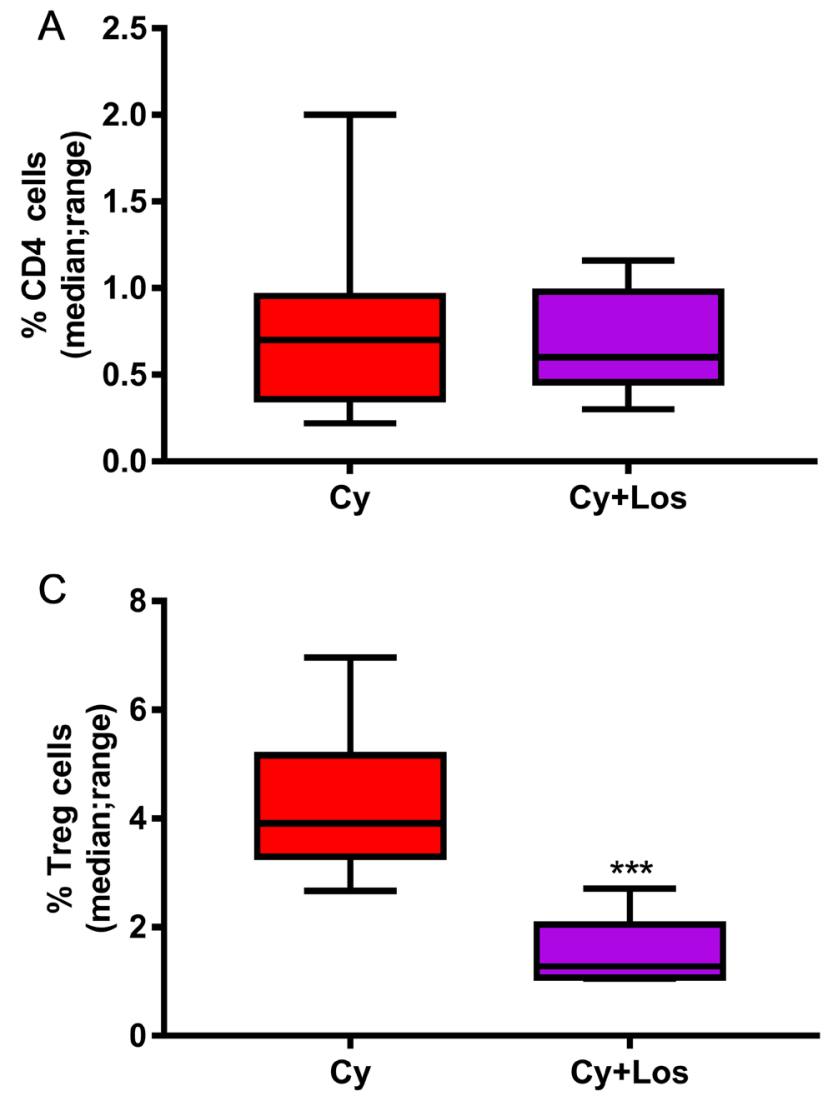

evaluation of different mechanisms of action that may be involved in the therapeutic effect.

The combined treatment significantly diminished the expression of the proliferation marker Ki67 in both tumor models and, simultaneously, increased the number of apoptotic cells in M-234p tumor, while there were no modifications in M-406 tumor. The induction of apoptosis in $\mathrm{M}-234 \mathrm{p}$ tumor cells would be responsible, at least in part, for the higher efficacy of the treatment in this tumor model.

The first and most studied mechanism of action of metronomic chemotherapy was its effect on angiogenesis. The antiangiogenic effect of $\mathrm{Cy}$ has been widely validated [5, 17, 32]. Moreover, other authors have already demonstrated that Los can cause inhibition of angiogenesis $[28,33]$. Recently, several studies have demonstrated that the main effect of the antiangiogenic activity of metronomic chemotherapy is the vascular normalization [34]. Metronomic Cy was demonstrated to improve drug uptake and tumor oxygenation in a preclinical model [35]. Besides, Los diminishes the solid stress that compresses tumor blood vessels, achieving a similar result to vascular normalization through microenvironment normalization; this effect is mediated by the reduction of collagen production which results in decompression of tumor capillaries [16]. A qualitative analysis of the tumor
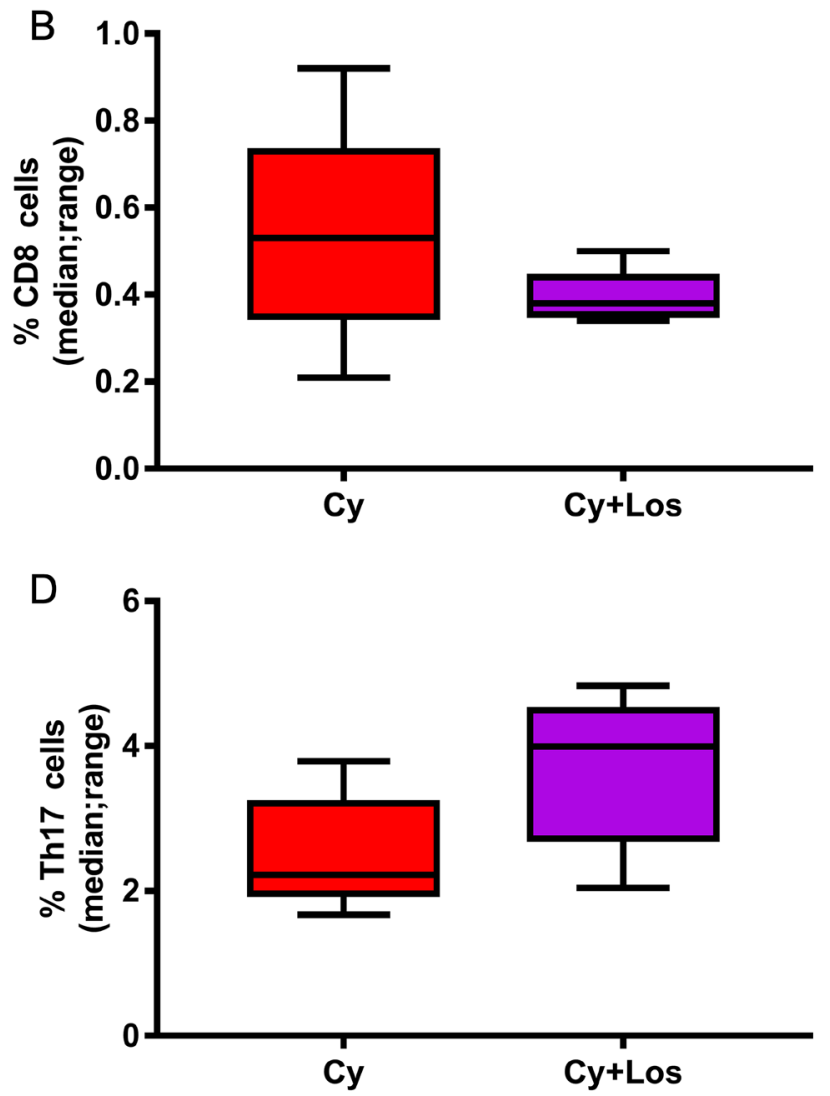

Figure 6: Quantification of tumor infiltrating lymphocytes by flow cytometry: M-234p, day 42, Cy vs Cy+Los: (A) CD4 cells, N. S. (B) CD8 cells, N. S. (C) Treg cells, $(P<0.001)$. (D) Th17 cells, $(P<0.05)$. Kruskal-Wallis multiple comparison test and Dunn's post-test. 
samples from the different groups has indicated that only the combined treatment produced a morphological and structural switch that resembles a vasculature found in normal mammary tissue, while neither Cy nor Los produced, individually, any change compatible with vascular normalization. On the other hand, in both tumor models, we found a significant and similar decrease of HIF 1- $\alpha$ in tumor samples from animals treated with $\mathrm{Cy}$ alone or with $\mathrm{Cy}+\mathrm{Los}$. This outcome indicates, at least

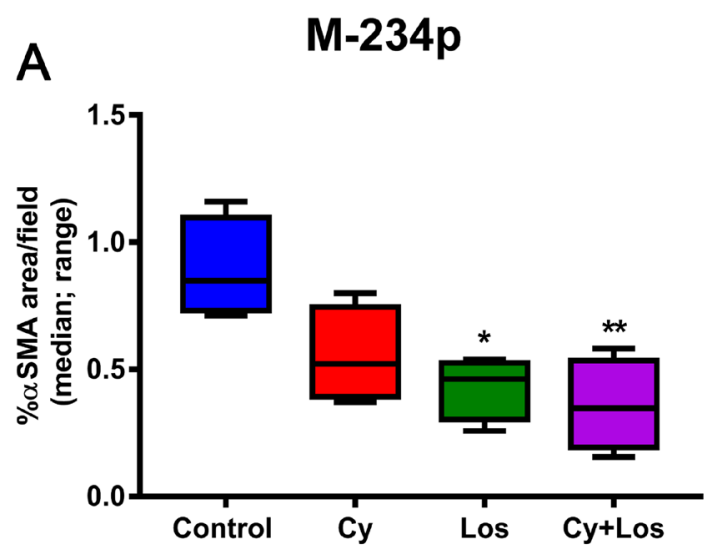

C
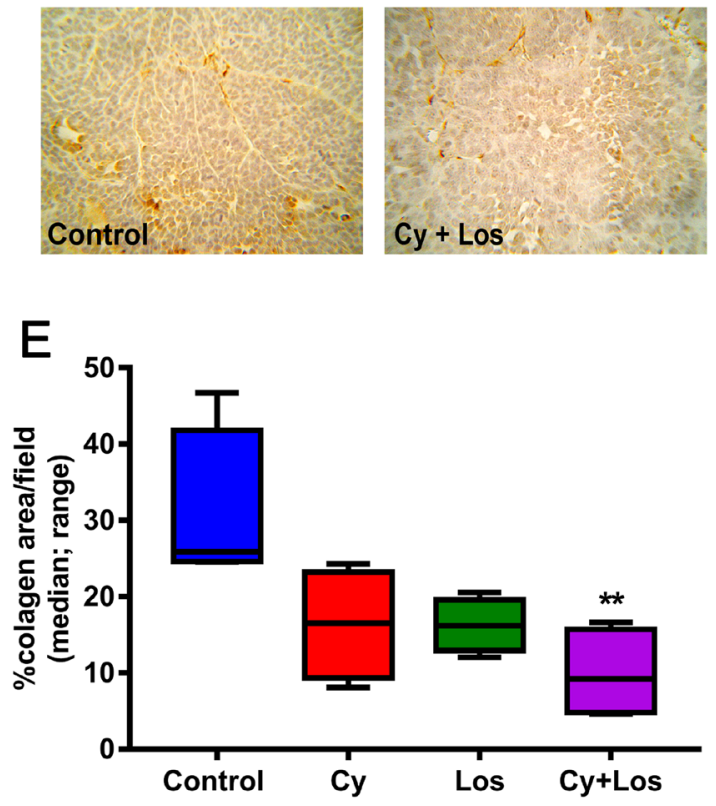

G

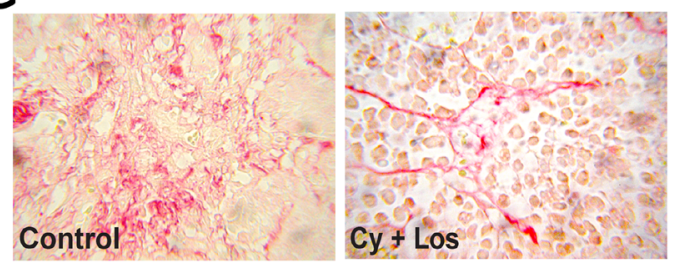

from the HIF1- $\alpha$ perspective, no participation of Los on angiogenesis, while it confirms the antiangiogenic effect of Cy previously observed [11]. These results indicate that the treatment with Cy plus Los may produce vascular normalization with vessels that have similar morphology to that of normal mammary tissue, increasing tumor oxygenation, reducing hypoxia and, as a consequence, improving the intratumor distribution and delivery of drugs, hence leading to a better therapeutic outcome.

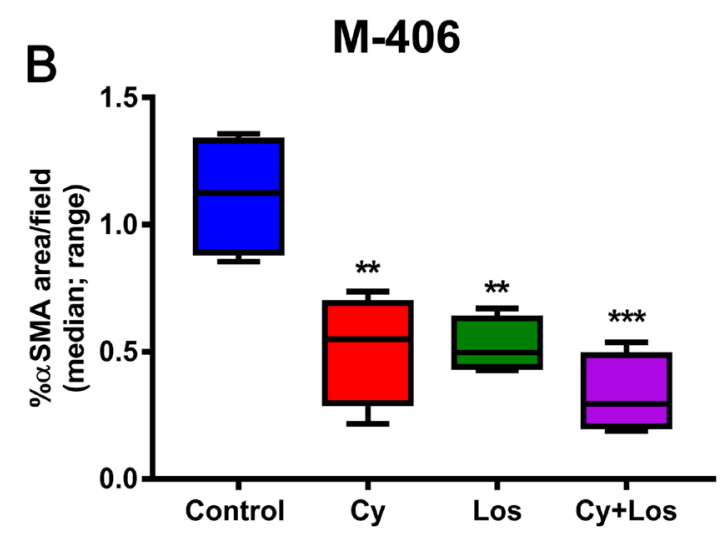

D

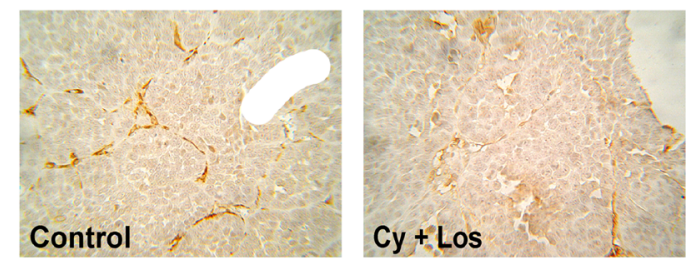

$\mathbf{F}$

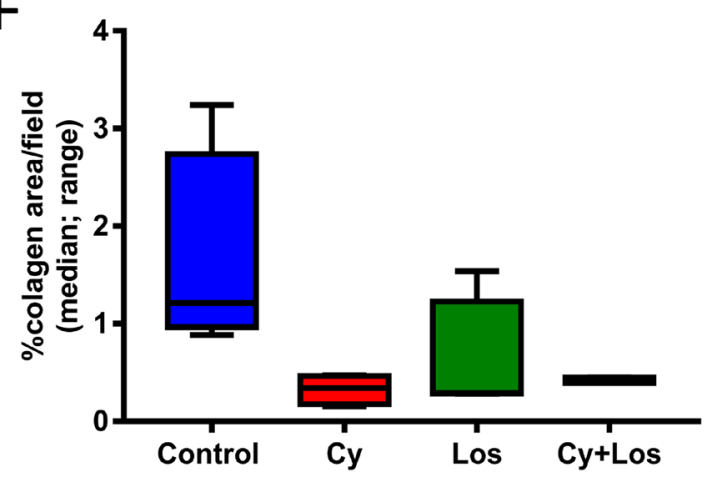

$\mathrm{H}$

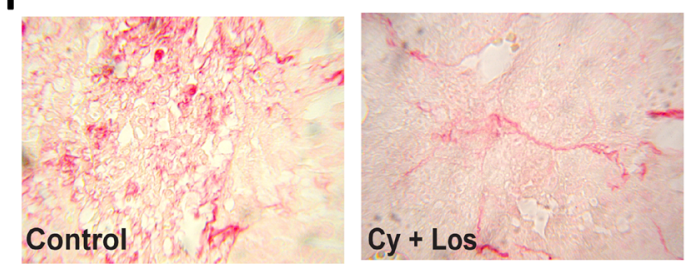

Figure 7: $\alpha$ SMA expression and collagen area. $\alpha S M A$ : \% of $\alpha S M A^{+}$area/field (median, range). (A) M-234p Control vs Los, $(P<0.05)$, vs Cy+Los, $(P<0.01)$. (B) M-406 Control vs Cy, $(P<0.01)$, vs Los $(P<0.01)$, vs Cy+Los $(P<0.001)$. (C) M-234p and $(\mathbf{D})$ M-406 representative images of Control and $\mathrm{Cy}+$ Los treated tumors, $100 \times$ magnification. Kruskal-Wallis multiple comparison test and Dunn's post-test. Collagen: \% of collagen area/field (median, range). (E) M-234p Control vs Cy+Los $(P<0.01)$. (F) M-406 N. S. (G) M-234p and (H) M-406 representative images of Control and Cy+Los treated tumors, 100× magnification. 
As demonstrated by several groups, included our own, the administration of $\mathrm{Cy}$ in a metronomic fashion can improve the antitumor immune response [24, 36]. Metronomic administration of cyclophosphamide, have been proved to stimulate the immune response against the tumor, mainly by reducing regulatory $\mathrm{T}$ cells and increasing Th17 cells populations [37]. On the other hand, there is less evidence showing the effect of Los on the immune response. It was observed, in vitro, that Los decreased the secretion of TGF- $\beta$ by mononuclear cells [38]. Gabriele et al., suggested that Los may differently control the balance of inflammatory cytokines such as IL-6 and IL-8, in human periodontal fibroblasts [39]. Also, Coulson associated the inhibition of progression with reduction of mammary tumor cell proliferation and of pSTAT3, TNF $\alpha$ and IL-6 in Losartan-treated group compared to control group [40]. Based on those previous works, we wanted to know the behavior of different $\mathrm{T}$ cells populations when administering the novel combination of cyclophosphamide and losartan in mice bearing mammary tumors. In the present study we analyzed different populations of circulating and tumor infiltrating $\mathrm{T}$ lymphocytes to elucidate their role in the therapeutic effect. The percentage of CD4, CD8, Tregs and Th17 circulating cells showed no changes induced by the treatments in the M-234p model. On the contrary, in the M-406 model, there was a marginally significant decrease in Tregs and a significant increase in Th17 cells in the combined treated group. Both modifications may contribute to the therapeutic effect obtained.

The evaluation of the tumor infiltrating regulatory $\mathrm{T}$ cells in tumor samples taken on day 30 , revealed opposite results in the two models. The number of Treg cells in M-234p samples of $\mathrm{Cy}+\mathrm{Los}$ group, was significantly higher than those in the other groups, while in the M-406 samples of the combined treated group, the percentage of these cells was significantly lower, when compared to Control tumors. The M-406 results were in agreement with those obtained for circulating Tregs. On the other hand, those obtained in M-234p tumors, were the opposite of the expected ones. The idea that maybe the kinetics of Tregs participation could be different in this particular tumor model, led us to quantify this cell population in samples taken on the 42nd day of tumor evolution. Indeed, that was the case because, at this time point, in which the tumor volume of the $\mathrm{Cy}+$ Los group was significantly lower than that of the Cy treated group, Tregs cells had also decreased with respect to Cy group. Moreover, a significant increase of Th17 cells in the combined treated group was also observed. Thus, the diminution of suppressor Treg and the increase of Th17 cells populations may play an antitumor role at this stage of tumor treatment.

Therefore, it is clear that while the final results showed the same tendency in both tumor models, the kinetics of participation of immune cells populations was quite different. Such result is not surprising, considering that each tumor may well differ, not only in their immunogenicity but also in the crucial aspect of the interaction between the tumor and its microenvironment. Other cell populations involved in the anti-tumor immune response like macrophages or myeloid derived suppressor cells will be analyzed in future experiments.

The effect of Los on the tumor micro environment has already been reported [28, 41]. According to these authors, the main target of Los are the cancer associated fibroblasts (CAF), causing a reduction in the amount of collagen I, which thereby allowed a better distribution of any cytotoxic agent. We used the expression of aSMA and the amount of collagen as markers of CAF. In the present work, the therapeutic effect of $\mathrm{Cy}$ was significantly improved by the combination with Los in both tumor models. The immunohistochemistry analysis of tumor samples showed that the combined treatment significantly diminished the expression of $\alpha \mathrm{SMA}$ and the collagen deposition, indicating an inhibitory effect on the CAF population. The therapeutic results obtained with the combined treatment, could be explained, on the one hand, by the inactivation produced by Los on CAF and, on the other hand, by a putative mild cytotoxic effect that Cy could have on the same type of cells when, in spite of the low doses administered, they can reach more easily the tumor cell, due to the decrease in collagen in the tumor microenvironment.

To the best of our knowledge, this paper describes for the first time, the metronomic treatment of triple negative breast cancers with a combination of cyclophosphamide and losartan. The antitumor effect of the drugs combination caused not only a significant diminution in tumor growth and a higher overall survival, but also the achievement of complete tumor regressions in one of the tumor models. Importantly, the treatment was devoid of general toxicity, without showing weight loss, in spite of the long period of daily medication. We also gained insight into some of the mechanisms responsible for the therapeutic effect obtained.

The therapeutic achievements obtained with $\mathrm{Cy}+\mathrm{Los}$ treatment that were, by far, better than those obtained by us, utilizing different drug combinations $[11,12,42]$, together with other advantages like low cost, oral administration and lack of toxicity, leading to a better quality of life, strongly suggest its translation to the clinical setting in the near future.

\section{MATERIALS AND METHODS}

\section{Animals}

Six week-old inbred $\mathrm{CBi}$ [43] and $\mathrm{BALB} / \mathrm{c}$ female mice were obtained from the Institute of Experimental Genetic breading facilities. Animals were fed with commercial chow and water ad libitum and were maintained in a 12-h light/dark cycle. All the experiments 
were developed during the first half of the light cycle. The animals were treated in accordance to the Canadian Council on Animal Care guidelines.

\section{Drugs}

Cyclophosphamide (Filaxis, SA, Argentina) was diluted to a stock concentration of $20 \mathrm{mg} / \mathrm{ml}$ by the addition of sterile distilled water. The stock solution was diluted at a concentration of $0.083 \mathrm{mg} / \mathrm{ml}$ in the drinking water, in order to reach a daily dose of $25 \mathrm{mg} / \mathrm{kg}$ of body weight per animal.

Losartan (Parafarm, Argentina) was diluted to a stock concentration of $166 \mathrm{mg} / \mathrm{ml}$. The stock solution was diluted at a concentration of 0.5 or $0.67 \mathrm{mg} / \mathrm{ml}$ in the drinking water, so it can be reached a daily dose of 150 or $200 \mathrm{mg} / \mathrm{kg}$ of body weight per animal (M-406 and M-234p models, respectively).

The optimum doses of cyclophosphamide and losartan were established previously [11, 12, 44, 45].

\section{Tumors}

M-234p and M-406 mouse triple negative mammary tumors established in our laboratory were used. M-234p is a type B moderately differentiated mammary adenocarcinoma [46] that shows a mixed pattern and develops lung metastasis. This tumor, which arose in a $\mathrm{BALB} / \mathrm{c}$ female mouse, is maintained in vivo by serial s. c. passages in syngeneic mice, with an incidence of $100 \%$. M-406 is a type B semi-differentiated mammary adenocarcinoma histologically similar to M-234p, spontaneously arisen in a $\mathrm{CBi}$ female mouse. It is maintained in vivo by serial i.p. passages in syngeneic mice, with an incidence of $100 \%$.

\section{Experimental model}

Adult BALB/c or CBi female mice were implanted orthotopically in the mammary fat pad with $\mathrm{M}-234 \mathrm{p}$ or M-406 tumor fragments $\left(1-\mathrm{mm}^{3}\right)$, respectively. Five (M-234p) or eight (M-406) days later, when the tumors were palpable, the animals were distributed in four groups (M-234p: $n=6-7 /$ group; M-406: $n=5-6 /$ group) and treated as follows: Control: regular drinking water without drug administration; Cy: $25 \mathrm{mg} / \mathrm{kg}$ bw/day of Cy in the drinking water; Los: $200 \mathrm{mg} / \mathrm{kg}$ bw/day (M-234p) and 150 $\mathrm{mg} / \mathrm{kg}$ bw/day (M-406) in the drinking water; Cy+Los: Cy and Los treatments combined. The drinking water for each experimental group was replaced every other day. The animals were controlled daily and weighed three times per week. Tumor sizes were measured with Vernier calipers, and tumor volumes were calculated as follows: $\mathrm{V}=0.4$ $\left(\mathrm{ab}^{2}\right)$, where $\mathrm{V}=$ volume $\left(\mathrm{mm}^{3}\right), \mathrm{a}=$ largest diameter $(\mathrm{mm})$, $\mathrm{b}=$ smallest diameter $(\mathrm{mm})$. Different endpoints were set for survival analysis and to obtain tumor and blood samples. For survival analysis, each mouse was euthanized when it reached the maximum tumor volume ethically permitted; for tumor and blood samples collection, all the animals were euthanized when Control group tumors reached the maximum volume ethically permitted (day 22 and day 31 for M-406 and M-234p, respectively). On an additional experiment developed with the M-234p model, tumor samples of $\mathrm{Cy}$ and $\mathrm{Cy}+\mathrm{Los}$ groups, were taken on day 42, a time point when mice from Control and Los groups had already been euthanized because of their tumor burden. In all the experiments, tumors were excised immediately after euthanasia, and processed for histology and immunohistochemistry.

\section{Histological and immunohistochemical studies}

Excised tumors were fixed in $10 \%$ buffered formalin and were paraffin-embedded. Five- to six-micrometer thickness sections were obtained, deparaffinized and used for: 1) Hematoxylin-Eosin staining, using standard techniques, to analyze the structure and morphology of tumor capillaries; 2) Immunohistochemical analysis, antigens were unmasked by heating the sections at $95^{\circ} \mathrm{C}$ in $10 \mathrm{mmol} / \mathrm{L}$ citrate buffer with $\mathrm{pH} 6.0$, for $15 \mathrm{~min}$, and immunostaining was undertaken using the specific primary antibodies, CD4 (sc-13573, 1/400, Santa Cruz Biotechnology), CD8 (sc-18913, 1/400, Santa Cruz Biotechnology), Foxp3 (\#14477480, 1/50, eBioscience), Ki67 (\#12202, 1/400, Cell Signaling), HIF-1 $\alpha$ (MA116518, 1/5000, Thermo Fisher) and aSMA (ab5694, $1 / 300$, Abcam). The antigen was visualized using the Vectastain Elite ABC kit (Vector Lab., Burlingame, CA), following manufacturer's instructions. Sections were then treated with 3,3'-diaminobenzidine (Sigma) as a chromogen, for $5 \mathrm{~min}$, and were lightly counterstained with soft hematoxylin. Negative controls were performed avoiding the primary antibody. Slides were washed in tap water, dehydrated, and mounted with glass coverslips; 3 ) Apoptosis, tumor sections were immunostained by the TUNEL method (In Situ Cell Death Detection Kit, Roche); 4) Collagen quantification, tumor sections were stained with Picro-Sirius Red staining (Direct Red 80 Sigma).

\section{Quantification}

The positive cells for CD4, CD8, Foxp3, Ki67 and HIF- $1 \alpha$ were counted in 30 fields $(1000 \times)$; $\alpha$ SMA and collagen areas were evaluated with Image $J$ software in 30 fields $(1000 \times)$.

\section{Flow cytometry}

Blood samples and tumor cells suspensions were used to evaluate circulating and tumor infiltrating CD4 (\#550954, 1/400, BD Bioscience), CD8 (\#22150084, 1/200, Immunotools), Treg (CD4 ${ }^{+}$, Foxp3 ${ }^{+}$[\#560401, 1/300, BD Bioscience]) and Th17 (CD4 ${ }^{+}$, IL-17 ${ }^{+}$ 
[\#559502, 1/400, BD Bioscience]) positive cells by flow cytometry using a FACSARIA II cytometer. Acquired data were analyzed with flowing software version 2 .

\section{Statistics}

Data obtained was analyzed using ANOVA and Tukey-Kramer Multiple Comparison tests, Kruskal-Wallis and Dunn's post-test, and Log-rank tests were used to examine the differences between groups with GraphPad Prism version 3.0 (GraphPad Software, San Diego, CA).

\section{ACKNOWLEDGMENTS}

We thank the scholarships given by INC (Instituto Nacional del Cáncer, Argentina) to CDK, by CONICET (Consejo Nacional de Investigaciones Científicas y Tecnológicas) to MVB and ADG and by Facultad de Ciencias Médicas, UNR. to MCG and MF. We thank Juan Manuel Cáceres who participated in the graphics and figures design.

\section{CONFLICTS OF INTEREST}

The authors declare that there is no conflicts of interest regarding the publication of this paper.

\section{FUNDING}

The work was supported by grants from UNR (Universidad Nacional de Rosario) to OGS.

\section{REFERENCES}

1. Bray F, Ferlay J, Soerjomataram I, Siegel RL, Torre LA, Jemal A. Global cancer statistics 2018: GLOBOCAN estimates of incidence and mortality worldwide for 36 cancers in 185 countries. CA Cancer J Clin. 2018; 68:394 424. https://doi.org/10.3322/caac.21492. [ [PubMed]

2. Cruz-Munoz W, Francia G, Kerbel RS. Metronomic chemotherapy for treatment of metastatic disease: from preclinical research to clinical trials. In: Lyden D, Welch DR, and Tsaila B, eds. Cancer Metastasis Biologic Basis and Therapeutics. New York: Cambridge University Press; 2011:573-586. https://doi.org/10.1017/ CB09780511976117.052.

3. Browder T, Butterfield CE, Kraling BM, Shi B, Marshall B, O'Reilly MS, Folkman J. Antiangiogenic scheduling of chemotherapy improves efficacy against experimental drugresistant cancer. Cancer Res. 2000; 60:1878-1886. [PubMed]

4. Klement G, Baruchel S, Rak J, Man S, Clark K, Hicklin DJ, Bohlen P, Kerbel RS. Continuous low-dose therapy with vinblastine and VEGF receptor-2 antibody induces sustained tumor regression without overt toxicity. J Clin Invest. 2000; 105:R15-R24. https://doi.org/10.1172/JCI8829. [PubMed]
5. Hanahan D, Bergers G, Bergsland E. Less is more, regularly: metronomic dosing of cytotoxic drugs can target tumor angiogenesis in mice. J Clin Invest. 2000; 105:10451047. https://doi.org/10.1172/JCI9872. [PubMed]

6. Kerbel RS, Kamen BA. The anti-angiogenic basis of metronomic chemotherapy. Nat Rev Cancer. 2004; 4:423436. https://doi.org/10.1038/nrc1369. [PubMed]

7. Ghiringhelli F, Menard C, Puig PE, Ladoire S, Roux S, Martin F, Solary E, Le Cesne A, Zitvogel L, Chauffert B. Metronomic cyclophosphamide regimen selectively depletes CD4+CD25+ regulatory $\mathrm{T}$ cells and restores $\mathrm{T}$ and NK effector functions in end stage cancer patients. Cancer Immunol Immunother. 2007; 56:641-648. https:// doi.org/10.1007/s00262-006-0225-8. [PubMed]

8. Pantziarka P, Bouche G, Meheus L, Sukhatme V, Sukhatme VP, Vikas P. The Repurposing Drugs in Oncology (ReDO) Project. Ecancermedicalscience. 2014; 8:485. https://doi. org/10.3332/ecancer.2014.485. [PubMed]

9. Andre N, Banavali S, Snihur Y, Pasquier E. Has the time come for metronomics in low-income and middle-income countries? Lancet Oncol. 2013; 14:e239-e248. https://doi. org/10.1016/S1470-2045(13)70056-1. [PubMed]

10. Mainetti LE, Rozados VR, Bonfil RD, Scharovsky OG. Metronomic therapy with cyclophosphamide or doxorubicin inhibits mouse mammary adenocarcinoma growth and metastasis development. Proc Amer Assoc Cancer Res. 2005; 46:5852.

11. Mainetti LE, Rozados VR, Rossa A, Bonfil RD, Scharovsky OG. Antitumoral and antimetastatic effects of metronomic chemotherapy with cyclophosphamide combined with celecoxib on murine mammary adenocarcinomas. J Cancer Res Clin Oncol. 2011; 137:151-163. https://doi. org/10.1007/s00432-010-0869-9. [PubMed]

12. Mainetti LE, Rico MJ, Fernandez-Zenobi MV, Perroud HA, Roggero EA, Rozados VR, Scharovsky OG. Therapeutic efficacy of metronomic chemotherapy with cyclophosphamide and doxorubicin on murine mammary adenocarcinomas. Ann Oncol. 2013; 24:2310-2316. https:// doi.org/10.1093/annonc/mdt164. [PubMed]

13. Johnston CI. Angiotensin receptor antagonists: focus on losartan. Lancet. 1995; 346:1403-1407. https://doi. org/10.1016/S0140-6736(95)92411-6. [PubMed]

14. Habashi JP, Judge DP, Holm TM, Cohn RD, Loeys BL, Cooper TK, Myers L, Klein EC, Liu G, Calvi C, Podowski M, Neptune ER, Halushka MK, et al. Losartan, an AT1 antagonist, prevents aortic aneurysm in a mouse model of Marfan syndrome. Science. 2006; 312:117-121. https://doi. org/10.1126/science.1124287. [PubMed]

15. Cohn RD, van Erp C, Habashi JP, Soleimani AA, Klein EC, Lisi MT, Gamradt M, ap Rhys CM, Holm TM, Loeys BL, Ramirez F, Judge DP, Ward CW, et al. Angiotensin II type 1 receptor blockade attenuates TGF-beta-induced failure of muscle regeneration in multiple myopathic states. Nat Med. 2007; 13:204-210. https://doi.org/10.1038/nm1536. [PubMed]

16. Chauhan VP, Martin JD, Liu H, Lacorre DA, Jain SR, Kozin SV, Stylianopoulos T, Mousa AS, Han X, Adstamongkonkul 
P, Popovic Z, Huang P, Bawendi MG, et al. Angiotensin inhibition enhances drug delivery and potentiates chemotherapy by decompressing tumour blood vessels. Nat Commun. 2013; 4:2516. https://doi.org/10.1038/ ncomms3516. [PubMed]

17. Man S, Bocci G, Francia G, Green SK, Jothy S, Hanahan D, Bohlen P, Hicklin DJ, Bergers G, Kerbel RS. Antitumor effects in mice of low-dose (metronomic) cyclophosphamide administered continuously through the drinking water. Cancer Res. 2002; 62:2731-2735. [PubMed]

18. Pietras K, Hanahan D. A multitargeted, metronomic, and maximum-tolerated dose "chemo-switch" regimen is antiangiogenic, producing objective responses and survival benefit in a mouse model of cancer. J Clin Oncol. 2005; 23:939-952. https://doi.org/10.1200/JCO.2005.07.093. [PubMed]

19. Shahrzad S, Shirasawa S, Sasazuki T, Rak JW, Coomber BL. Low-dose metronomic cyclophosphamide treatment mediates ischemia-dependent K-ras mutation in colorectal carcinoma xenografts. Oncogene. 2008; 27:3729-3738. https://doi.org/10.1038/sj.onc.1211031. [PubMed]

20. Tang TC, Man S, Lee CR, Xu P, Kerbel RS. Impact of metronomic UFT/cyclophosphamide chemotherapy and antiangiogenic drug assessed in a new preclinical model of locally advanced orthotopic hepatocellular carcinoma. Neoplasia. 2010; 12:264-274. https://doi.org/10.1593/ neo.91872. [PubMed]

21. Shaked Y, Emmenegger U, Francia G, Chen L, Lee CR, Man S, Paraghamian A, Ben-David Y, Kerbel RS. Lowdose metronomic combined with intermittent bolus-dose cyclophosphamide is an effective long-term chemotherapy treatment strategy. Cancer Res. 2005; 65:7045-7051. https://doi.org/10.1158/0008-5472.CAN-05-0765. [PubMed]

22. Bertolini F, Paul S, Mancuso P, Monestiroli S, Gobbi A, Shaked Y, Kerbel RS. Maximum tolerable dose and lowdose metronomic chemotherapy have opposite effects on the mobilization and viability of circulating endothelial progenitor cells. Cancer Res. 2003; 63:4342-4346. [PubMed]

23. Rozados VR, Sanchez AM, Gervasoni SI, Berra HH, Matar P, Graciela Scharovsky O. Metronomic therapy with cyclophosphamide induces rat lymphoma and sarcoma regression, and is devoid of toxicity. Ann Oncol. 2004; 15:1543-1550. https://doi.org/10.1093/annonc/mdh384. [PubMed]

24. Rozados VR, Mainetti LE, Rico MJ, Zacarias Fluck MF, Matar P, Scharovsky OG. The immune response and the therapeutic effect of metronomic chemotherapy with cyclophosphamide. Oncol Res. 2010; 18:601-605. https:// doi.org/10.3727/096504010X12777678141662. [PubMed]

25. Perroud HA, Rico MJ, Alasino CM, Queralt F, Mainetti LE, Pezzotto SM, Rozados VR, Scharovsky OG. Safety and therapeutic effect of metronomic chemotherapy with cyclophosphamide and celecoxib in advanced breast cancer patients. Future Oncol. 2013; 9:451-462. https://doi. org/10.2217/fon.12.196. [PubMed]

26. Yazdannejat H, Hosseinimehr SJ, Ghasemi A, Pourfallah TA, Rafiei A. Losartan sensitizes selectively prostate cancer cell to ionizing radiation. Cell Mol Biol. 2016; 62:30-33. [PubMed]

27. Zhao Y, Cao J, Melamed A, Worley M, Gockley A, Jones D, Nia HT, Zhang Y, Stylianopoulos T, Kumar AS, Mpekris F, Datta M, Sun Y, et al. Losartan treatment enhances chemotherapy efficacy and reduces ascites in ovarian cancer models by normalizing the tumor stroma. Proc Natl Acad Sci U S A. 2019; 116:2210-2219. https://doi.org/10.1073/ pnas.1818357116. [PubMed]

28. Diop-Frimpong B, Chauhan VP, Krane S, Boucher Y, Jain RK. Losartan inhibits collagen I synthesis and improves the distribution and efficacy of nanotherapeutics in tumors. Proc Natl Acad Sci U S A. 2011; 108:2909-2914. https:// doi.org/10.1073/pnas.1018892108. [PubMed]

29. Xiao L, Hu SQ, Wang LY, Liu JX, Li XY. Losartan improves the distribution and efficacy of doxorubicin in CT26 tumor. Eur Rev Med Pharmacol Sci. 2015; 19:37633769. [PubMed]

30. Rose A, Andre N, Rozados VR, Mainetti LE, Menacho Marquez M, Rico MJ, Schaiquevich P, Villarroel M, Gregianin L, Graupera JM, Garcia WG, Epelman S, Alasino C, et al. Highlights from the 1st Latin American meeting on metronomic chemotherapy and drug repositioning in oncology, 27-28 May, 2016, Rosario, Argentina. Ecancermedicalscience. 2016; 10:672. https://doi. org/10.3332/ecancer.2016.672. [PubMed]

31. Andre N, Tsai K, Carre M, Pasquier E. Metronomic Chemotherapy: Direct Targeting of Cancer Cells after all? Trends Cancer. 2017; 3:319-325. https://doi.org/10.1016/j. trecan.2017.03.011. [PubMed]

32. Wang R, Qin S, Chen Y, Li Y, Chen C, Wang Z, Zheng $\mathrm{R}, \mathrm{Wu} \mathrm{Q}$. Enhanced anti-tumor and anti-angiogenic effects of metronomic cyclophosphamide combined with Endostar in a xenograft model of human lung cancer. Oncol Rep. 2012; 28:439-445. https://doi.org/10.3892/or.2012.1828. [PubMed]

33. Otake AH, Mattar AL, Freitas HC, Machado CM, Nonogaki S, Fujihara CK, Zatz R, Chammas R. Inhibition of angiotensin II receptor 1 limits tumor-associated angiogenesis and attenuates growth of murine melanoma. Cancer Chemother Pharmacol. 2010; 66:79-87. https://doi. org/10.1007/s00280-009-1136-0. [PubMed]

34. Mpekris F, Baish JW, Stylianopoulos T, Jain RK. Role of vascular normalization in benefit from metronomic chemotherapy. Proc Natl Acad Sci U S A. 2017; 114:19941999. https://doi.org/10.1073/pnas.1700340114. [PubMed]

35. Doloff JC, Khan N, Ma J, Demidenko E, Swartz HM, Jounaidi Y. Increased tumor oxygenation and drug uptake during anti-angiogenic weekly low dose cyclophosphamide enhances the anti-tumor effect of weekly tirapazamine. 
Curr Cancer Drug Targets. 2009; 9:777-788. https://doi. org/10.2174/156800909789271503. [PubMed]

36. Rico MJ, Rozados VR, Mainetti LE, Zacarias Fluck MF, Matar P, Scharovsky OG. Regulatory T cells but not NKT I cells are modulated by a single low-dose cyclophosphamide in a B cell lymphoma tumor-model. Exp Oncol. 2012; 34:38-42. [PubMed]

37. Sistigu A, Viaud S, Chaput N, Bracci L, Proietti E, Zitvogel L. Immunomodulatory effects of cyclophosphamide and implementations for vaccine design. Semin Immunopathol. 2011; 33:369-383. https://doi.org/10.1007/s00281-0110245-0. [PubMed]

38. Kaynar K, Ulusoy S, Ovali E, Vanizor B, Dikmen T, Gul S. TGF-beta and TNF-alpha producing effects of losartan and amlodipine on human mononuclear cell culture. Nephrology (Carlton). 2005; 10:478-482. https://doi. org/10.1111/j.1440-1797.2005.00462.x. [PubMed]

39. Gabriele LG, Morandini AC, Dionisio TJ, Santos CF, Angiotensin II. Type 1 Receptor Knockdown Impairs Interleukin-1beta-Induced Cytokines in Human Periodontal Fibroblasts. J Periodontol. 2017; 88:e1-e11. https://doi. org/10.1902/jop.2016.160354. [PubMed]

40. Coulson R, Liew SH, Connelly AA, Yee NS, Deb S, Kumar B, Vargas AC, O'Toole SA, Parslow AC, Poh A, Putoczki $\mathrm{T}$, Morrow RJ, Alorro $\mathrm{M}$, et al. The angiotensin receptor blocker, Losartan, inhibits mammary tumor development and progression to invasive carcinoma. Oncotarget. 2017; 8:18640-18656. https://doi.org/10.18632/oncotarget.15553. [PubMed]

41. Kumar V, Boucher Y, Liu H, Ferreira D, Hooker J, Catana C, Hoover AJ, Ritter T, Jain RK, Guimaraes AR. Noninvasive
Assessment of Losartan-Induced Increase in Functional Microvasculature and Drug Delivery in Pancreatic Ductal Adenocarcinoma. Transl Oncol. 2016; 9:431-437. https:// doi.org/10.1016/j.tranon.2016.07.004. [PubMed]

42. Rico M, Baglioni M, Bondarenko M, Laluce NC, Rozados V, Andre N, Carre M, Scharovsky OG, Menacho Marquez M. Metformin and propranolol combination prevents cancer progression and metastasis in different breast cancer models. Oncotarget. 2017; 8:2874-2889. https://doi. org/10.18632/oncotarget.13760. [PubMed]

43. Vasconi MD, Bertorini G, Codina AV, Indelman P, Di Masso RJ, Hinrichsen LI. Respuesta a la selección divergente por conformación corporal en el ratón. Mendeliana. 1991; 9:13.

44. Bish LT, Yarchoan M, Sleeper MM, Gazzara JA, Morine KJ, Acosta P, Barton ER, Sweeney HL. Chronic losartan administration reduces mortality and preserves cardiac but not skeletal muscle function in dystrophic mice. PLoS One. 2011; 6:e20856. https://doi.org/10.1371/journal. pone.0020856. [PubMed]

45. Fraune C, Lange S, Krebs C, Holzel A, Baucke J, Divac N, Schwedhelm E, Streichert T, Velden J, Garrelds IM, Danser AH, Frenay AR, van Goor H, et al. AT1 antagonism and renin inhibition in mice: pivotal role of targeting angiotensin II in chronic kidney disease. Am J Physiol Renal Physiol. 2012; 303:F1037-F1048. https://doi. org/10.1152/ajprenal.00672.2011. [PubMed]

46. Squartini F, Pingitore R. Tumours of the mammary gland. IARC Sci Publ. 1994; 111:47-100. [PubMed] 